\title{
NON-CONVENTIONAL/ILLEGAL POLITICAL PARTICIPATION OF MALE AND FEMALE YOUTHS
}

\author{
CLAIRE GAVRAY, BERNARD FOURNIER, MICHEL BORN
}

\begin{abstract}
Belgian data from the PIDOP project show that boys are more involved than girls in illegal political actions, namely the production of graffiti and other acts of "incivility". These activities must be considered in both groups as complementary to conventional political and social participation and not as their opposite. The main explanatory factor is the level of the perceived efficaciousness of such actions. The lack of trust in institutions and the level of awareness of societal discrimination play no significant explanatory role. In males, the involvement level in these activities depends on feelings of personal discrimination and on the lack of freedom concerning individual choice, confirming the theory of societal vulnerability and Honneth's theory of recognition. This level also increases along with increasing opportunities to make acquaintances and have fun in the neighbourhood. In females, this involvement is explained by the distance with regard to pro-sociality level.
\end{abstract}

Key words: Belgium; youth; non-conventional political participation; theory of societal vulnerability; Honneth's theory of recognition; gender theory

Studies of political participation have traditionally distinguished between conventional and non-conventional, and legal and illegal modes of participation (John, Fieldhouse and Liu 2011). Data collected as part of the PIDOP project provide an opportunity to identify non-conventional/illegal political actions among young people, actions such as writing messages or graffiti with a political message on walls or participating in radical actions such as burning flags, etc. The aim of this paper is to shed more light on the individual factors which could explain such actions among male and female adolescents. Three hypotheses are tested in this paper. Firstly, that these actions are linked to conventional forms of political and social activities; secondly, that they ensue from concrete life experiences; thirdly, to establish the impact of gendered socialisation and expectations on the probability of non-conventional/ illegal political actions but also on the dynamics of explanatory factors.

\section{Can non-conventional political participation be explained by the theories of societal vulnerability and recognition?}

According to the theory of societal vulnerability (Vettenburg, Walgrave and Van Kerkhove 1984; Walgrave 1992), the most disadvantaged young people behave in a most 
problematic and delinquent way because they do not have the opportunity to create a positive, stable relationship with society and because they feel repeatedly neglected, discriminated against, and even excluded by society's different institutions (family, school, justice, police, even the job market, etc). The social reaction to non-conformist behaviours, in turn, contains the risk of stigmatisation and may eventually trigger a process leading to systematic delinquency. To begin with, the theory highlights the fact that juvenile delinquency is both defined and controlled in the context of inequality of social power, where certain groups of the population have an interest in seeing these actions criminalised. Conversely, the members of the groups that have the least power to negotiate struggle to see their specific interests and needs met and they are subjected to harsh stereotyping. Although the forms of symbolic domination and cultural legitimacy are changing nowadays, the basic processes remain unchanged. The psychosocial dynamics are indeed at the heart of this theory in that it is the feeling of discrimination which prompts the young to react. Thus, societal vulnerability is not a symptom of economic vulnerability. Social belonging and the risks which pertain to it cannot be reduced to a single indicator. They are situated at the intersection of an ensemble of complementary dimensions, revealed by Bourdieu (1979) incidentally. A major contribution by this French sociologist is that he has shown how the different types of capital (economic, social, and symbolic capital) create at the same time both unequal social relationships and class "habitus". According to Chauvel (2001, 345), the question of hierarchies and the fight against inequality have progressively been replaced by struggles for the recognition of specificities and differences, with a structure of symbolic affiliations instead of economic and social ones. The psychologising of the social cohesion and the increasing individualisation of our societies seem to lead a large number of young people to experience their suffering as a personal destiny of failure, rather than to apprehend the difficulties in their social and societal components (Duret 1999). In this context, the demands will be more individual than collective now. The work of Stephan et al. (2000) confirms that discrimination, penury and threat, as well as the behaviours which are mobilised to deal with them, differ according to the social group of belonging. The young people who are the most fragile and suffer the most from "subjective" comparison with their peers are more at risk of rebelling against the institutions they feel display unfairness and aggressiveness, even though this rebellion does not necessarily reveal an efficient and definitive solution.

Through his work, Bourdieu introduces another powerful idea. He asserts that fights and power relationships are the motors of social cohesion rather than putting a strain on it. He is followed on this point by Honneth. This contemporary philosopher and sociologist is known for his theory of recognition (Honneth 1999; 2004), in which links with the theory of societal vulnerability can be seen in so far as he insists on the lesions which foster the experience and feelings of injustice and contempt (Honneth 2006), and on their issues.

The idea he defends is that these lesions and related risks need to be linked to the process of recognition, of which he distinguishes three forms. The first form refers to intimacy and affects self-confidence. The second form aims at the equal worth of people and is based on the law. The third one refers to opportunities for making social contributions, one of the principal dimensions being employment, which allows self-esteem to be established. Correspondingly, Honneth defines different kinds of contempt, among them physical violence, legal exclusion and the violation of human dignity. For him, moral experiences 
are linked to the way individuals interpret social exchanges and the social reality with which they are confronted. Honneth defines the process of social integration and of citizenship as one that does not exclude conflict between social agents in logic of communication in a broad sense which has to lead to mutual recognition. In doing so, he distances himself from the theory of deliberative democracy, according to which only rational choice and general and formal discourses are at the origin of a procedure of deliberations which must lead to just and correct decisions. Honneth supports the idea that the assumption of deliberative democracy is not neutral because it also favours citizens who have achieved a certain level of education and who have developed the faculties of discourse and argumentation (Le Goff $2006,5)$. It largely obscures the power relations and reifies the institutions. Beyond that, it renders criticism impossible and illegitimate.

\section{The contribution of gender theory}

Gender stereotyped beliefs and behaviours are still present in our contemporary society (Gavray 2010). Research in political science confirms that political interest and "classical" involvement are always less popular among young girls (Briggs 2008; Dalton 2008; Gallego 2007). Moreover, the gender group remains a significant factor in the explanation of delinquency (Egli, Vettenburg, Savoie, Lucia, Gavray and Zeman 2010). Criminological studies confirm that nowadays, the lower the number of investigated offences is and the more they involve violence, the more the difference between male and female adolescents remains important (Heidensohn 1995; Cario 1997; Vettenburg, Gavray and Born 2010). Research has shown for a long time that if gender specificity appears, it is more in terms of the intensity of delinquent activity than in terms of specific psychosocial mechanisms (Hirshi 2004). Both girls and boys react to situations that make them fragile and insecure (Carlen 1998). Other research highlights the specificities of the situations young people encounter: the type of insecurity or discrimination, the place where they appear (Gavray 2009). Gender theory invites us to think that the differences observed here may be linked to gender socialisation and to the state of social relations which develops between the gender groups and between what is defined on the masculine and feminine side (Worrall 2001; Chesney-Lind 2002; Bereni et al. 2008; Gavray 2010).

At the very moment when young men, and specifically those who lose out in ongoing developments, feel that their chances are narrowing and that they might manifest a specific resentment against school and the social and political organisation of society (Duret 1999), an ever-increasing proportion of young girls is becoming aware of the new opportunities offered by favourable legislation and regulation as well as by school certification-a passport which gives them access to individualisation, to intellectual development and to civic and political participation (Marry 2004; Gavray 2010).

These considerations led us to examine empirically whether the level of implication in non-conventional/illegal political action might depend less on abstract political opinions and ideas and on an awareness of social and institutional inequalities, and more on the concrete life experiences of young people in different spheres of life. 


\section{Method}

Participants

The PIDOP study (Processes Influencing Democratic Ownership and Participation) is a European project studying civic and political participation of young people between 16 and 26 years of age. In this project, two strategies were followed.

To cover the youngest people in the sample, we decided first to build a representative sample of French-speaking secondary school students in the administrative districts of Brussels-Capital and Liege (a large city in Wallonia). Data were collected from 851 pupils in the fifth and sixth years of secondary school (minimum age was 16; 145 pupils were 19 or 20 years old). There were 56 classes who participated, drawn from general, technical and vocational education. Girls represented $53 \%$ of the surveyed pupils. This higher female percentage corresponds to the reality at the end of secondary school. Of our respondents $69 \%$ stated that both their parents had been born in Belgium, which corresponds to the percentage we found in two previous studies with the same methodology and on the same urban territory (unfortunately, no official statistics exist on this issue).

Secondly, the Belgian sample had to be completed with a non-random sample of a further 379 older participants. We respected the quotas required for the PIDOP study: three "national" populations (the majority and two minority groups, namely Moroccans and Turks), two age groups (16-17 and 18-26), and two gender groups (these quotas were like Russian dolls). We had to use a snowball method as well as field associations to reach enough Moroccan and Turkish young people. An online version of the questionnaire was also used to gain access to the oldest population.

In total, 1230 individuals were reached, with 524 (42\%) belonging to the 18-26 age category. The proportion of girls remains slightly higher (54\%). Concerning national origin, as we had to choose and overrepresent two "ethnic minorities", 59.1\% of respondents' parents were born in Belgium; $12.6 \%$ had at least one parent born in Turkey; $14.3 \%$ had at least one parent born in Morocco; and 14\% had at least one parent born somewhere other than in Belgium, Turkey or Morocco.

\section{Procedure}

A questionnaire was used to collect the data. The questionnaire was initially prepared in English and then translated into the different languages of the participating countries in the PIDOP project using appropriate translation and back translation procedures. The questionnaire asked participants detailed questions about their participation in associations, activities, and political and social actions. The questionnaire also contained many other questions relating to the experiences of the young, their opinions, visions, and projects. The variables which were used for the present analyses were as follows.

As the dependent variable, we used a score of non-conventional/illegal political actions (NCA). This represents the sum of the answers to two questions coded from 1 (never) to 5 (very often). These questions are related to activities largely considered to be non-civic and illegal: 
- In the last 12 months, have you written messages or graffiti with a political message on walls?

- In the same period, have you participated in illegal actions such as burning a flag...? The correlation between these two variables is $.56(\mathrm{p}<0.0001)$.

As independent variables to test, we used a first set of identification variables: age group (AGE) - 16-17 and 18-26; gender (GND) - $\mathrm{M}=1$ and $\mathrm{F}=2$; speaking French at home (LANG) - scale of three positions; type of education followed in secondary school (EDUC) - general, technical or vocational; evaluation of financial well-being of the household (WB) - scale of four positions.

A second set of variables concerned the core of the questionnaire and of our hypotheses:

- The first variable concerned the perception of the efficaciousness of non-conventional/ illegal actions (EFFNC), namely the sum of the auto-evaluated efficaciousness of graffiti and other illegal actions (in each case, with a five-point scale from "not at all" to "very"); here there was a correlation of .43 .

- The feeling of personal discrimination (DISCR) was measured by the answer on a fiveposition scale to the question "Have you ever felt excluded or discriminated against?"

- A scale concerning the level of perceived opportunities to make acquaintances and have fun in the neighbourhood (CLIMATE) was built as the sum of the answers (five positions from $1=$ not true at all to $5=$ totally true) to four propositions: "In this neighbourhood, there are enough activities for young people"; "In this neighbourhood, there are opportunities to meet other boys and girls"; "In this neighbourhood, there are many events and situations which involve young people like me"; "In this neighbourhood, young people can find many opportunities to have fun". Alpha was .82.

- A global score of trust in institutions (TRUST) was built as the sum of the answers to nine specific questions (scale of five positions) concerning trust in the European Union, Federal government, Regional government, Local council/government, schools/colleges/ universities, Courts, Police force, Political parties and other public organisations and services. Alpha was .81.

- Another cumulative score concerned the level of freedom regarding personal choices (FREE). It concerned five items with five positions: use of contraceptives, having friends, a boy- or girl-friend, career choices regarding school or work, religion and faiths. Alpha was .74.

- A score of conventional political/civic participation (CP) was constructed on the basis of the sum of answers on the frequency of a set of actions (five positions from never" to "every day") : "Sign a petition (including on-line petitions)"; "Attend a public meeting or demonstration dealing with political or social issues"; "Do volunteer work, wear a bracelet sign or other symbol to show support for a social or political cause", "Distribute leaflets with a political content", "Write about politics or societal issues, e.g. in a student's newspaper, organisation journal, or on the internet (e.g. blogs)"; "Discuss societal or political questions on the net", "Boycott or buy certain products for political, ethical or environmental reasons"; "Take part in associations in favour of human rights, environment or in another association with a civic or social aim". Alpha was .81.

- Another score concerned the level of general interest in politics (INTP) on the basis of answers to three questions concerning political discussions: "I discuss social and 
political topics with my friends and relatives"; "I bring political and social issues into my discussions with others", "I am interested in politics" (answer from $1=$ "not true at all" to 5 = "very true"). Alpha was .82 .

- Another variable concerned the pride of personal religious or philosophical convictions (REL) (scale from 1 = "not at all important" to 5 "very important").

- Another variable concerned the feeling of being a member of a particular group of the population (MEMB) (social, ethnic, gender). The scale ran from 1 = "not at all important" to 5 "very important".

- Another variable concerned awareness of societal discrimination towards specific groups in Belgium (AWDISC). The scale ran from 1 = "not at all important" to 5 "very important".

- A pro-sociality variable (PROSO) was related to the answer to the following question: "When someone is unfairly accused, to what extent do you stand up for him or her?", answered on as five-point scale.

Stepwise procedure (Forward under SAS) regression analyses were used to reveal the factors that were linked to participants' positioning on the scale of non-conventional/illegal political actions. This regression procedure enters the variables to be tested in a sequence dependent on their contribution to $\mathrm{R}^{2}$. The procedure ends when there is no additional significant contribution by including the remaining variables. Our analysis remains explanatory. A table of correlations is available in the Appendix. It uses abbreviations following the names of the different variables as indicated above.

\section{Results}

In our sample, 70 boys out of 533 respondents and 76 girls out of 643 respondents said that they had written graffiti. We also recorded 83 boys out of 543 respondents and 87 girls out of 663 saying that they had participated in illegal actions such as burning a flag. However, we cannot be sure that these actions and behaviours sent out political messages.

The gender difference mostly concerned the intensity/frequency of such illegal actions. The GLM procedure $(\mathrm{p}=0.03$ ) confirmed that there was a significant link between a built level of non-conventional/illegal political actions and the gender group. When the "gender group" was included among the variables tested by the regression procedure on the whole sample, the results confirmed a higher level of non-conventional/illegal actions among boys ( $\mathrm{p}=0.01$ ). The model which results from the stepwise analysis had an R-square of .28 and was significant at $\mathrm{p}<0.0001$. But our aim here is to perform statistical regression separately for both gender groups. Indeed, most of the time, when the analysis is performed on a mixed sample and is supposed to be gender neutral, the results reveal some significant factors specific to boys and to girls.

\section{In the male group}

At step 11, the model proved to be highly significant $(\mathrm{p}<0.0001)$ and the proportion of explained variance (R-square) was 0.33 . 
Table 1. Explanatory model of the level of non-conventional/illegal actions obtained by the regression analysis - forward selection - step 11 - boys

\begin{tabular}{|l|c|c|c|c|}
\hline & $\begin{array}{c}\text { Parameter } \\
\text { Estimate and sign }\end{array}$ & $\begin{array}{c}\text { Standard } \\
\text { Error }\end{array}$ & F Value & Pr > F \\
\hline Intercept & 1.78 & 0.50 & 12.65 & $\begin{array}{c}0.0004 \\
* * *\end{array}$ \\
\hline $\begin{array}{l}\text { Level of feeling of personal } \\
\text { discrimination }\end{array}$ & 0.16 & 0.45 & 6.31 & $\begin{array}{c}0.0004 \\
* * *\end{array}$ \\
\hline Level of trust in institutions & -0.00 & 0.00 & 0.83 & $\begin{array}{c}0.3633 \\
\mathrm{NS}\end{array}$ \\
\hline $\begin{array}{l}\text { Level of freedom regarding } \\
\text { personal choices }\end{array}$ & -0.04 & 0.01 & 8.96 & $\begin{array}{c}0.0030 \\
* *\end{array}$ \\
\hline Level of pro-sociality & -0.03 & 0.04 & 0.59 & $\begin{array}{c}0.4425 \\
\mathrm{NS}\end{array}$ \\
\hline $\begin{array}{l}\text { Level of conventional political/ } \\
\text { civic participation }\end{array}$ & 0.04 & 0.01 & 10.58 & $\begin{array}{c}0.0013 \\
* *\end{array}$ \\
\hline Level of interest in politics & -0.03 & 0.01 & 5.25 & $\begin{array}{c}0.0227 \\
*\end{array}$ \\
\hline $\begin{array}{l}\text { Speaking French at home/other } \\
\text { language }\end{array}$ & -0.19 & 0.10 & 3.26 & $\begin{array}{c}0.0720 \\
\mathrm{NS}\end{array}$ \\
\hline $\begin{array}{l}\text { Level of perceived opportunities } \\
\text { of acquaintances and fun in the } \\
\text { neighbourhood }\end{array}$ & 0.10 & 0.03 & 10.39 & $\begin{array}{c}0.0014 \\
* *\end{array}$ \\
\hline $\begin{array}{l}\text { Pride in personal religious or } \\
\text { philosophical convictions }\end{array}$ & -0.03 & 0.03 & 1.11 & $\begin{array}{c}0.2925 \\
\mathrm{NS}\end{array}$ \\
\hline $\begin{array}{l}\text { Awareness of societal } \\
\text { discrimination in Belgium }\end{array}$ & 0.05 & 0.03 & 2.64 & $\begin{array}{c}0.1052 \\
\mathrm{NS}\end{array}$ \\
\hline $\begin{array}{l}\text { Perception of the efficaciousness } \\
\text { of non-conventional/illegal actions }\end{array}$ & 0.03 & 36.37 & $\begin{array}{c}<0.0001 \\
* * *\end{array}$ \\
\hline
\end{tabular}

$* * *: \mathrm{p}<0.001 * *: \mathrm{p}<0.01 *: \mathrm{p}<0.05 \mathrm{NS}=$ not significant. Model strongly significant $\mathrm{p}<$ $0.0001(\mathrm{~F}=12.88)$.

Table 1 confirms six significant factors. Age group and frequency of French language use plays no role here. We find that the following have a major impact: the perception of the efficaciousness of the illegal actions carried out, the level of conventional political/civic participation, the level of perceived opportunities for making acquaintances and having fun in the neighbourhood, the level of freedom regarding personal choices, the feeling of personal discrimination and the level of general interest in politics.

Our three hypotheses seem to be confirmed here.

The level of non-conventional/illegal political action is positively related to the level of conventional political/civic action, although, at the same time, boys carrying out such actions affirm having a lower general interest in politics.

We also verify that greater discrimination or limited personal choices have a significant 
effect. These factors emerge when the level of financial well-being is not retained by the model and is definitively not significant. The type of education in secondary school, which clearly operates as a social/economic cleavage in Belgium, does not appear to be a direct explanatory factor.

One may also advance the idea that these subjective feelings and frustrations have something to do with the social injunction of autonomisation/individual empowerment affecting male adolescents, due to the fact they have interiorized the right to be free, to be actors of their choices and decisions, at an early age. The results show that what we called "perceived opportunities for making acquaintances and having fun but in the neighbourhood" had a positive effect. The adolescents involved in non-conventional/illegal political actions are not isolated or lonely. They evaluate positively the opportunity they have to make social contacts and carry out leisure activities in their immediate environment.

Pride in personal religious or philosophical convictions, the feeling of being a member of a particular group of the population, the level of pro-sociality or the level of trust in institutions does not play any explanatory role here. Awareness of societal discrimination towards specific groups in Belgium plays no role either.

\section{In the female group}

The retained model was also highly significant in the girls' group but to a slightly lesser extent than in the boys' group. The proportion of explained variance (R-square) was .25 here. After nine steps, the process stopped due to a lack of significant supplementary contribution. The number of significant items explaining the level of non-conventional/illegal actions was fewer compared to the male group. We still find that the age group, the language spoken at home or financial well-being have no effect. Pride in personal religious or philosophical convictions or the feeling of being a member of a particular group of the population have no impact. And there was still no impact caused by the level of trust in institutions or awareness of societal discrimination towards specific groups.

We note straight away that the perception of efficaciousness of non-conventional/illegal actions, followed by the level of conventional political/civic actions had a strong effect, as was the case in the male group. Our first hypothesis stating that conventional and nonconventional/illegal political actions are not separable but are closely linked is verified. Nevertheless, we find that the level of general interest in politics, feelings of personal discrimination the restriction of personal choices, and opportunities to make acquaintances and have fun in the neighbourhood have no effect. So, the second hypothesis is not verified here.

In contrast, a third (and new) significant explanatory factor appears only among girls and young women: the level of pro-sociality.

How could gendered socialisation and expectations help in interpreting these results? It has been shown that gender stereotypes continue to influence our objective and subjective experiences. Many studies demonstrate that, despite real change in this area, girls and young women are still expected to be less involved in the public sphere and in groups, while they are expected to be the main providers of care and the moral guardians of pro-social values. It is logical that girls who are the most involved in non-conventional/illegal actions (actions 
Table 2. Explanatory model of the level of nonconventional/illegal actions obtained by the regression analysis - forward selection - step 9 - girls

\begin{tabular}{|l|c|c|c|c|}
\hline & $\begin{array}{c}\text { Parameter } \\
\text { Estimate and sign }\end{array}$ & $\begin{array}{c}\text { Standard } \\
\text { Error }\end{array}$ & F Value & Pr > F \\
\hline Intercept & 1.29 & 0.23 & 31.26 & $\begin{array}{c}<0.0001 \\
* * *\end{array}$ \\
\hline $\begin{array}{l}\text { Level of feeling of personal } \\
\text { discrimination }\end{array}$ & -0.02 & 0.02 & 0.94 & $\begin{array}{c}0.3331 \\
\text { NS }\end{array}$ \\
\hline Level of trust in institutions & -0.00 & 0.00 & 0.55 & $\begin{array}{c}0.4591 \\
\text { NS }\end{array}$ \\
\hline $\begin{array}{l}\text { Level of freedom regarding } \\
\text { personal choices }\end{array}$ & 0.01 & 0.00 & 2.09 & $\begin{array}{c}0.1487 \\
\text { NS }\end{array}$ \\
\hline Level of pro-sociality & -0.06 & 0.02 & 9.46 & $\begin{array}{c}0.0023 \\
* *\end{array}$ \\
\hline $\begin{array}{l}\text { Level of conventional political/ } \\
\text { civic participation }\end{array}$ & 0.02 & 0.00 & 22.19 & $\begin{array}{c}<0.0001 \\
* * *\end{array}$ \\
\hline $\begin{array}{l}\text { Level of interest in politics } \\
\text { Pride in personal religious or } \\
\text { philosophical convictions }\end{array}$ & -0.01 & 0.00 & 3.33 & $\begin{array}{c}0.0688 \\
\mathrm{NS}\end{array}$ \\
\hline $\begin{array}{l}\text { Awareness of societal } \\
\text { discrimination in Belgium }\end{array}$ & -0.02 & 0.17 & 1.38 & $\begin{array}{c}0.2186 \\
\mathrm{NS}\end{array}$ \\
\hline $\begin{array}{l}\text { Perception of the efficaciousness } \\
\text { of non-conventional illegal } \\
\text { actions }\end{array}$ & 0.15 & 0.02 & 47.66 & $\begin{array}{c}<0.0001 \\
* * *\end{array}$ \\
\hline
\end{tabular}

$* * *: \mathrm{p}<0.001 * *: \mathrm{p}<0.01 *: \mathrm{p}<0.05 \mathrm{NS}=$ not significant. Model strongly significant $\mathrm{p}<$ $0.0001(\mathrm{~F}=12.53)$.

considered more as violent male behaviours) are particular distant towards the pro-social attitudes attributed to their gender group.

Concerning the limitation of personal choices and the level of perceived personal victimisation, many studies confirm higher rates for boys/men than for girls/women. This is, for instance, the case in studies concerning domestic violence or juvenile delinquency using general samples. In our sample, the level of self-rated personal choice is on average a little higher among the young women (an average of 18.8 with a standard deviation of 2.2 for the girls, against an average of 17.7 for the boys with a standard deviation of 3.4 which is higher than for the girls $-\mathrm{p}<0.0001)$. We also confirm a slightly higher level of self-related personal discrimination in the male group $(\mathrm{p}=0.03)$. This result is interesting considering that other studies show that young girls today are still more controlled by the family, more driven towards restricting their ambitions, towards repressing their frustrations, and towards avoiding comparing themselves too much with others (expressions of symbolic violence according to Bourdieu 1979, and of well-intentioned discrimination according to Delacolette et al. 2009). Young girls are still less driven towards becoming autonomous and gaining 
their place in a competitive world and in the public sphere, even though, together, they are becoming more and more confident in their abilities and in their right to broaden their spheres of development and identity.

Some studies show that male and female victimisation experiences are not similar, with more social and public victimisation in the former group, and more private and family victimisation in the latter group. With the PIDOP data, we found that the perceived reasons for discrimination are partly different for boys and girls. Of the female subjects, $13 \%$, as opposed to $3 \%$ of the male subjects, reported that they felt that discrimination occurred because of their gender affiliation $(\mathrm{p}=0.0002)$. Regarding the places where discrimination occurred, the only place which showed a significant gender difference was the family, for $26 \%$ of the girls and $17 \%$ of the boys $(\mathrm{p}=0.03)$. Young people, mainly boys, seem to have experienced discrimination at school. It would be interesting to analyse with more finesse the impact of societal vulnerability on non-conventional/illegal political actions, not using quantitative research but qualitative research, before concluding that the theory of societal vulnerability does not apply to girls.

\section{Discussion}

Several results suggest interesting conclusions. The main explanatory factor of nonconventional/illegal actions was a strong belief in the efficaciousness of this kind of action ${ }^{1}$. These actions maintain over time. This is confirmed by high correlations between the past experience of both types of illegal actions we considered (graffiti and illegal behaviours), the intention of (re)producing these actions, and the perception of the efficaciousness of such actions (correlations of .60 and $\mathrm{p}<0.0001$ in each case).

The analysis confirmed that, at an individual level, non-conventional/illegal actions are significantly related to other types of political and civic participation which are considered legitimate and worthy of support. Thus, it is particularly important not to stigmatise too readily non-conventional/illegal political expression. In both gender groups, it appears that the propensity to write messages on walls and other forbidden places, to burn flags or to carry out other actions on the fringes of legality, cannot be considered as simple acts of juvenile delinquency. This hypothesis has been confirmed for both girls and boys.

The motivation behind non-conventional/illegal actions is not to defend a social/political ideal of equality or justice. Our results show that collective awareness of the discrimination which concerns the organisation of society has no influence. As Chauvel $(2001,357)$ has pointed out: "The current veneration of autonomy would necessarily imply diagnosing the real capital and freedoms which young people effectively enjoy in the various social groups constituting the society". The level of trust in institutions is also not significant in the model.

For boys, the restrictions and the negative psychosocial experiences of everyday life proffer an additional explanation for the behaviour studied and not social and economic belonging in the strict sense of the word. This finding, albeit modest, confirms our second hypothesis. It supports the theory of societal vulnerability and Honneth's theory of

${ }^{1}$ In focus groups and individual interviews from another part of the PIDOP project, the idea emerged
that some participants thought that a little bit of violence is sometimes the only solution which is heard. 
recognition. Indeed, the non-conventional/illegal actions investigated depend significantly on the subjective feeling of discrimination, on cumulative frustrations and limitations, and on the absence of recognition of the needs related to the male identity in construction. The second hypothesis is only confirmed for boys. In the female group, illegal political actions do not seem to occur in reaction to great subjective personal discrimination or to strong limitations of personal choices. The girls and young women who have most experience of non-conventional/illegal political actions-which is less frequent than in the male groupstand out as having distanced themselves from pro-social attitudes.

In both gender groups, the variables concerning cultural origin and religious pride do not appear as significant in the models. According to Ndobo (2010,48), such a result challenges the primacy of the multicultural Anglo-Saxon model which is nowadays "leading to the substitution of a view of a social world and phenomena divided into social classes by one of a vision of a mosaic of ethnicised communities".

Our third broad hypothesis makes sense. The results obtained from the separate analyses carried out on the male and female groups oblige us to question the analysis and the results in the light of gender social mechanisms. On one hand, we can find traces of the perpetuation of the gender socialisation and injunctions directed towards the two different gender groups. This is true for dependent and independent variables. On the other hand, if we compare with previous generations, more restrictive opportunities exist for those male adolescents thinking they have lost power compared to the generation of their fathers and experiencing frustration, and better opportunities exist for some girls becoming able to distance themselves from what have been established as feminine values and roles.

One must bear in mind that, historically also, most of the theories and analyses which strive to understand delinquent behaviour or illegal political participation have concerned male groups and were conceptualised on the basis of masculinity (Longshore, Turner, Stein 2006). From a methodological perspective, we can point out that experiences of discrimination which call for a reaction or compensation by the young girls experiencing illegal actions are perhaps not identified clearly enough by the selected available variables. ${ }^{2}$

\section{References}

Bereni, L., Chauvin, S., Jaunait, A., Revillard, A. (2008). Introduction aux Gender Sudies. Bruxelles: de Boeck.

Bourdieu, P. (1979). La distinction: critique sociale du jugement. Paris: Éditions de Minuit.

Briggs, J. E. (2008). Young Women and Politics: an Oxymoron. Journal of Youth Studies 11 (6), 579592.

Cario, R. (1997). Les filles résistent au crime. Paris: L'Harmattan.

Carlen, P. (1998). Women, Crime and Poverty. Philadelphia: Open University Press.

\footnotetext{
2 The research outlined here was supported by a grant received from the European Commission 7th Framework Programme, FP7-SSH-2007-1, Grant Agreement no: 225282, Processes Influencing Democratic Ownership and Participation (PIDOP) awarded to the University of Surrey (UK), University of Liège (Belgium), Masaryk University (Czech Republic), University of Jena (Germany), University of Bologna (Italy), University of Porto (Portugal), Örebro University (Sweden), Ankara University (Turkey) and Queen's University Belfast (UK).
} 


\begin{tabular}{|c|c|c|c|c|c|c|c|c|c|c|c|c|c|c|c|}
\hline 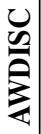 & & & & & & & & & & & & & & & $\infty$ * \\
\hline$\sum_{i=1}^{0}$ & & & & & & & & & & & & & & 二* & 은 \\
\hline 劉 & & & & & & & & & & & & & $\tilde{z}$ & 으 & 우 \\
\hline $\begin{array}{l}\overrightarrow{0} \\
\mathbf{2} \\
\underline{\mathbf{Z}} \\
\underline{\underline{Z}}\end{array}$ & & & & & & & & & & & & 으 * * & 우 $* *$ & 二 & กิ* \\
\hline$\tilde{v}$ & & & & & & & & & & & 守 $* * * *$ & g. $*$ & 으 * * & $\dot{n}$ & 구 \\
\hline 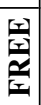 & & & & & & & & & & $\hat{\sigma}_{i} *$ & 二 & $\tilde{z}$ & $\because *$ & $\tilde{z}$ & 士 \\
\hline 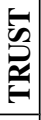 & & & & & & & & & $\stackrel{\infty}{*}$ & $\tilde{\text { 乙 }}$ & $\stackrel{\infty}{*} *$ & $\varnothing_{i} *$ & $\infty *$ & $\hat{o}_{i} *$ & z \\
\hline 窗 & & & & & & & & 士 & z & $\tilde{\mathbf{z}}$ & z & $\tilde{z}$ & $\infty *$ & $8 *$ & $\tilde{z}$ \\
\hline \begin{tabular}{|l|}
$\underline{0}$ \\
$\underline{\underline{\theta}}$ \\
\end{tabular} & & & & & & & $g_{i} *$ & $\underset{*}{*} *$ & $F_{i}^{*} *$ & 气 $*$ & $8 * *$ & $\stackrel{*}{*}$ & z & $\cong *$ & $8 *$ \\
\hline 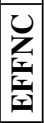 & & & & & & $\tilde{z}$ & $\tilde{z}$ & $\tilde{z}$ & $g_{i} *$ & 으 * & $\mathscr{*}$ & z & z & $\tilde{z}$ & Z \\
\hline 象 & & & & & z & $\overbrace{i}^{*} *$ & $8 *$ & $\infty$ * & $\because *$ & $\varrho_{i}$ & $8 *$ & $\tilde{z}$ & s. * & z & $\bar{z}$ \\
\hline \begin{tabular}{|l} 
\\
0 \\
0
\end{tabular} & & & & Э $* *$ & $\tilde{z}$ & z & $\tilde{z}$ & $\bar{I}_{i}^{*} *$ & $\hat{0}_{i} *$ & $\tilde{z}$ & 二 & $\tilde{z}$ & $\because *$ & $\tilde{z}$ & Z \\
\hline U & & & $\underset{*}{*}$ & $\simeq * *$ & $\tilde{z}$ & $\frac{2}{*}$ & $\tilde{z}$ & $\tilde{z}$ & 우 & $\Xi_{i} *$ & $\tilde{z}$ & $\stackrel{2}{7} *$ & $\simeq * * * *$ & b. $*$ & Z \\
\hline 䞤 & & $\frac{0}{*} *$ & ণิ & $\cong$ * & $\hat{o}_{i} *$ & $\stackrel{*^{\circ}}{*}$ & $\tilde{z}$ & $\hat{o}_{i}^{*} *$ & $\bar{z}$ & ণิ & ? & $\stackrel{\infty}{0} *$ & $\varnothing_{i}$ * & z & Z \\
\hline $\begin{array}{l}\mathbf{u} \\
\mathbf{z}\end{array}$ & 우 & Z & z & z & $\stackrel{\infty}{\sim}$ ^* & ㅇ․ * & $\subseteq * *$ & $\tilde{z}$ & $\infty_{i}^{\infty} *$ & ก) & $\tilde{z}$ & $\tilde{z}$ & $\tilde{z}$ & b. * & $\varnothing_{i}^{0} *$ \\
\hline & 团 & 岁 & 芑 & $\sum_{3}^{n}$ & 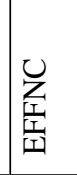 & 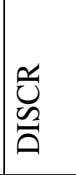 & 焉 &  & 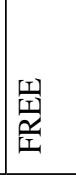 & 己 & 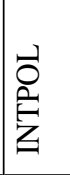 & 窉 & $\sum_{i=1}^{n}$ & 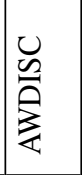 & $\begin{array}{l}0 \\
0 \\
0 \\
\text { \&. } \\
2\end{array}$ \\
\hline
\end{tabular}


Chauvel, L. (2001). Le retour des classes sociales? Revue de l'OFCE 79, 315-359.

Chesney-Lind, M. (2002). The Female Offender: Girls, Women and Crime (2nd ed.). Thousand Oaks: Sage.

Dalton, R. J. (2008). Citizenship Norms and Expansion of Political Participation. Political Studies 56, 76-98.

Delacolette, N., Dardenne, B., Dumont, M. (2009). Stéréotypes prescriptifs et avantages des groupes dominants. L'Année psychologique 101, 617-653.

Duret, P. (1999). Les jeunes et l'identité masculine. Paris: Presses universitaires de France.

Egli, N., Vettenburg, N., Savoie, J., Lucia, S., Gavray, C., Zeman, K. (2010). Belgium, Canada and Switzerland: are there Differences in the Contributions of Selected Variables on Property and Violent Self-Reported Delinquency? European Journal of Criminal Policy and Research 16 (3), 145-166.

Gallego, A. (2007). Inequalities in Political Participation. Contemporary Patterns in European Countries. Irvine: Center for Study of Democracy, University of California.

Gavray, C. (2009a). Délinquance juvénile et enjeux de genre. Interrogations, Revue en sciences de l'homme et de la société, Formes, figures et représentations des faits de déviance féminins, 8 juin.

Gavray, C. (2009b). Consommations et délinquances: deux expériences complémentaires à l'adolescence. In M. Guedah (Ed.). Délinquances et changements sociaux, des modes de vie et des pratiques d'intervention. Dialogue nord-sud, Rabat: Actes du 11ème colloque de l'Association des criminologues de langue française, 213-241.

Gavray, C. (2010). Valeurs et attitudes stéréotypées à l'adolescence: quels enjeux en matière de réussite et d'insertion scolaire? In C. Gavray and A. Adriaenssens (Eds.). Une fille = un garçon? Identifier les inégalités de genre à l'école pour mieux les combattre, pp. 19-37. Paris: L'Harmattan.

Heidensohn, F. (1995). Women and Crime. Basingstoke: MacMillan.

John, P., Fieldhouse, E., Liu, H. (2011). How Civic is the Civic Culture? Explaining Community Participation Using the 2005 English Citizenship Survey. Political Studies 59 (2), 230-252.

Honneth, A. (1999). Intégrité et mépris: principes d'une morale de la reconnaissance. Recherches sociologiques 30(2), 11-22.

Honneth, A. (2004). La théorie de la reconnaissance: une esquisse. Revue du MAUSS 1(23), 133-136.

Honneth, A. (2006). La Société du mépris. Paris: La Découverte.

Le Goff, A. (2006). Délibérations, conflits et coopération. Honneth critique Habermas: vers une redéfinition de la notion de démocratie délibérative. Paris: Université Paris X-Nanterre, Les cahiers de l'école doctorale, 5, 5-25.

Longshore, D., Turner-Rand, S., Stein, J. A. (2006). Self-Control in a Criminal Sample: an Examination of Construct Validity. Criminology 34 (2), 209-222.

Marry, C. (2004). Une révolution respectueuse: les femmes ingénieurs. Paris, Berlin: Perspectives sociologiques.

Ndobo, A. (2010). Les nouveaux visages de la discrimination. Bruxelles: de Boeck.

Stephan, W. G., Stephan, C. W. (2000). An Integrated Threat Theory of Prejudice. In S. Oskamp (Ed.). Reducing Prejudice and Discrimination, pp. 23-45. Mahwah, NJ: Lawrence Erlbaum.

Vettenburg, N., Walgrave, L., Van Kerkhove, J. (1984). Jeugdwerkloosheid, delinquentie en maatchappelijke kwetsbaarheid. Antwerpen/Arnhem: Kluwer/Gouda Quint.

Vettenburg, N., Gavray, C., Born, M. (2010). Belgium. In J. Junger-Tas, I. H. Marshall, D. Enzmann, M. Killias, M. Steketee, B. Gruszczynska (Eds.). Juvenile Delinquency in Europe and Beyond: Results of the Second International Self-Reported Study, pp. 29-46. London: Springer.

Walgrave, L. (1992). Délinquance systématisée des jeunes et vulnérabilité sociétale: essai de construction d'une théorie intégrative. Genève: Méridiens Klincksieck.

Worrall, A. (2001). Girls at Risk? Reflections on Changing Attitudes to Young Women's Offending. Probation Journal 8 (2), 86-92. 
Boul. du Rectorat 3

Université de Liège

4000 Liège, Belgique

E-mail: cgavray@ulg.ac.be

Vakgroep Politieke Wetenschappe

Vrije Universiteit Brussel

Pleinlaan 5

1040 Bruxelles, Belgique

E-mail: Bernard.Fournier@me.com

Boul. du Rectorat 3

Université de Liège

4000 Liège, Belgique

E-mail:mborn@ulg.ac.be 